\title{
DECISION-MAKING PROCESS DURING THE FULFILMENT OF MILITARY ASSIGNMENTS
}

\author{
Radek Mitáček ${ }^{\mathrm{a}}$, Tomáš Zeman ${ }^{\mathrm{b}}$, Jan Drozd ${ }^{\mathrm{c}}$, Luboš \\ Ondroušek ${ }^{\mathrm{d}}$, David Ullrich ${ }^{\mathrm{e}}$, Jiří Dvořák ${ }^{\mathrm{f}}$ \\ University of Defence in Brno, Faculty of Military Leadership, Brno, \\ Czech Republic \\ a e-mail: radek.mitacek@unob.cz, \\ ORCID iD: Thttp://orcid.org/0000-0003-2516-5963, \\ b e-mail: tomas.zeman2@unob.cz, \\ ORCID iD: Thttp://orcid.org/0000-0001-7269-4994, \\ c e-mail: jan.drozd@unob.cz, \\ ORCID iD: \$http://orcid.org/0000-0003-3257-0473, \\ de-mail: lubos.ondrousek@unob.cz, \\ ORCID iD: : http://orcid.org/0000-0001-9186-1655, \\ e e-mail: david.ullrich@unob.cz, \\ ORCID iD: - ittp://orcid.org/0000-0003-2682-8730, \\ f e-mail: jiri.dvorak@unob.cz, \\ ORCID iD: Thttp://orcid.org/0000-0001-6628-4091
}

http://dx.doi.org/10.5937/vojtehg65-15018

FIELD: Military Science

ARTICLE TYPE: Original Scientific Paper

ARTICLE LANGUAGE: English

Abstract:

The paper deals with the decision-making process in crisis management with focus on the Army of the Czech Republic (soldiers at the University of Defence in Brno). Within the research, 44 soldiers were monitored whilst managing various tactical situations during a three-week complex field training exercise. The soldiers were supposed to carry out the following combat assignments: fire control, battle order and radio operation. Prior the training, the soldiers filled out a questionnaire the questions in which corresponded with the above mentioned practical tasks. Based on the acquired outcomes, it may be stated that the assessment of theoretical solution of selected combat assignments among future squad leaders may be used for the prediction of how successful the management of such assignments may be in practice.

Key words: Army of the Czech Republic, soldier, infantry squad, decisionmaking process, crisis communication. 


\section{Reviewing the Literature}

Decision making is a part of everyday life of all people in a society. These days, full of emergency events caused either by people or nature, it is necessary to manage various situations correctly, timely and sufficiently. The decision-making processes play a significant role in security environment when fulfilling the assignments of state. Soldiers face life threatening situations almost every day whilst fulfilling the assignments in the Army of the Czech Republic (ACR), one of state security components. Stress is on the agenda every day. An infantry squad on patrol never knows what will happen. It may be a routine patrol without any unexpected situations, but it may also be a patrol with obstacles to be overcome, including e.g. enemy traps or enemy itself. Therefore, every soldier has to be prepared to face unfavourable emergency events. Faster, more accurate and more powerful information gaining is necessary, capable of being evaluated in the preparation and execution phases of the operation.

If we want to acquire decision making capabilities of higher quality among the ACR personnel, it will be necessary to introduce such activities which may realize such intention. Such activities may be as follows:

1) personnel selection, focused on people with personality prerequisites for a quality decision making or readiness to learn it;

2) education in the area of decision-making processes.

The personnel selection process uses various methods with various criteria validity, such as:

1) biographical data;

2) interview;

3) references;

4) test of expert knowledge;

5) tests of capabilities;

6) tests of personality;

7) simulated situations;

8) assessment centre (combination of the above mentioned methods, especially simulated situations).

Validity of personnel selection represents the relation between the values of an employed method (predictor) and a real criterion (drivers' accident rate, salesmen's sales results, superiors' assessment). Validity is mostly measured as a predictor-criterion correlation coefficient. The most proved tools of personnel selection include simulated situations, often tailored into the form of case studies. The quality preparation of simulated situations ideally proceeds in the following format: 
1) data collection in terrain (critical situations);

2) selection of suitable situations for testing (situations distinguishing between right and wrong behaviour, adequately demanding for the candidate and with clear assessment criteria);

3) presentation of situations to a sample group of respondents and collection of responses to individual items;

4) assessment of responses in points by a group of experts;

5) elaboration of a guide for testers.

The case study may be, according to particular conditions, in a written form in which candidates solve a problem or a set of problems, or in a form of a role-play in which candidates are participants in a fictitious situation and their reactions are assessed by an evaluator (or evaluators). (Hroník, 2002), (Hroník, 2007).

A number of research studies deal with the use of simulated situations for the prediction of future performance of policemen and monitor their validity. Love \& DeArmond (2007) observed required competences among 54 candidates for the post of a police sergeant and they stated the following ones:

1) providing advice to subordinates;

2) perceptiveness;

3) team leading;

4) problem solving;

5) oral communication;

6) written communication;

7) decisiveness;

8) stress tolerance;

9) planning and organization;

10) independence;

11) work.

The candidates went through a one-day assessment centre, which included the following fictitious situations: daily administration, oral presentation, group discussions, problem solving. (Love \& DeArmond, 2007). These were compared with the assessment of real problem solving and the quality of communication. The best problem solving predictors proved to be written communication skills $(r=0.86)$ and decisiveness (0.84), the best communication quality predictors were coping with stress $(r=0.79)$ and perceptiveness $(r=0.76)$.

The assessment centre is considered to be the most common and efficient method of selecting candidates for managerial posts. Israeli police have been using this candidate selection tool for many years. Dayan et al. (2002) assessed the validity of assessment centres as tools for selecting 
the candidates for work at police; the participants also went through psychological tests. The participants took part in basic training and were assigned various police posts. The research among 712 participants included psychological tests, simulated situations, and colleagues' assessment. They were in groups of 13 to 15 people and tasked to manage the situations similar to those from common police practice (e.g. to confiscate debtors' assets, to evacuate protesters, to search for suspects, to arrest suspects, etc.), design a project (e.g. a campaign to hire new policemen), and prepare a five-minute verbal presentation on a given topic. They were assessed by a psychologist and an experienced police officer on scale from 1 to 7 . Their results were compared with the superiors' assessments after two years of practice, as well as with superiors' regular assessments and colleagues' regular assessments. The validity of simulated situations was high especially in relation to the training $(r=0.34)$ and work success rate $(r=0.43)$. Personality inventories had significantly lower validity (although statistically significant).

\section{Research Methodology}

During the research, soldiers were monitored when managing various tactical situations during a 3-day complex field training exercise, which took place from 28th February to 2nd March 2017 in the Březina Military Training Area. The aim of the complex field training exercise was to verify outcomes from the learning process in the accredited subject called Field Training II. In the second class, the students are trained to be squad commanders. A student should be capable of independent decisionmaking as a squad commander not only in tactical situations, but in the whole range of activities related to that post. He/she should be capable of implementing the individual steps of a planning and decision-making process on a squad level, so called Troop Leading Procedure (TLP). $\mathrm{He} / \mathrm{she}$ should be able to analyse a situation from the platoon commander combat documents, determine options for the solution of a given task, make a decision and elaborate a squad commander battle order. The outcomes from learning on this stage of training also include the issuing of battle order in terrain. There were 44 soldiers, students from the University of Defence, participating in the training exercise.

During the training exercise the soldiers completed long movements in terrain with low food supplies and little time for rest and sleeping. Besides that, the soldiers had to fulfil given assignments while being assessed on the scale from 0 to 10 points. 
1) Fire control:

It includes the target (enemy) identification, determination of its distance and direction, and issuing the fire order, or the fire assignment to the squad, or a weapon.

2) Battle order:

It includes the elaboration of the battle order based on the battle order from a superior level (platoon) while applying all steps of the TLP. The assessment was aimed mainly at a correct decision in relation to a tactical situation and the way the battle order was issued (the form of passing one's own decision to subordinates).

3) Radio operation:

It includes putting a RF-13 radiostation into operation, establishing connection and fulfilling pre-set operational assignments.

At the beginning, the soldiers were given a theoretical questionnaire (see Table 1) to be filled in. The questionnaire was designed in such a way that individual questions corresponded to the above mentioned practical assignments. The answers were assessed by the same evaluators on the basis of the same criteria as in practical training. The assessment of each soldier in research was thus based on both practical and theoretical solutions of individual tasks.

Table 1 - Questionnaire

Таблица 1 - Анкета-опросник

Табела 1 - Упитник

\begin{tabular}{|l|l|}
\hline Combat assignment & \multicolumn{1}{c|}{ Questions } \\
\hline Fire control & $\begin{array}{l}\text { Write the types of fire orders and describe in detail, which } \\
\text { information "full fire order" has to include. Write the ways of } \\
\text { target designation and describe in detail, which information } \\
\text { "direct target designation" has to include. }\end{array}$ \\
\hline Battle order & $\begin{array}{l}\text { How do you proceed when issuing battle order and what do } \\
\text { you have to pay attention to? }\end{array}$ \\
\hline Radio operation & $\begin{array}{l}\text { How do you put a radio station into operation? What is a } \\
\text { shortened form of a report (SALTR) transmitted to superior } \\
\text { and subordinate radio stations? What information has to be } \\
\text { included in it? What do you have to pay attention to? }\end{array}$ \\
\hline
\end{tabular}

The aim of the research was to verify statistically the relation between theoretical readiness and success to manage given tasks in practice. The Wilcoxon signed-rank test was used to test the difference between the outcomes achieved by the monitored group of soldiers in theoretical and practical parts of individual tasks. Then Spearman's rank correlation coefficient was used to assess the strength of links between the scores in theoretical and practical parts. 


\section{Outcomes and Discussion}

The outcomes of fulfilling individual combat assignments differed from each other significantly (see Table 2, Figures 1-3). The soldiers' outcomes in the theoretical questionnaire were better than subsequent practical execution in case of all assignments. This difference was statistically significant only in the case of "battle order" though. The outcomes in the practical part were much worse than in the theoretical one in this case. The assessment of the practical part was clearly the lowest of all the monitored assignments (average assessment 6.6). It may be assumed on the basis of such outcome that the practical fulfilment of the assignment "battle order" is much more difficult than its theoretical mastering. At the same time, the practical fulfilment of this particular assignment is significantly more difficult than in the case of other assessed assignments. The poor mastering of this assignment can be determined by the following factors:

1) It is a highly complex assignment;

2) The students were asked to fulfil this assignment for the first time;

3) The students do not have experience with acting in a commander role and are not able to interpret their decisions formally.

Issuing the battle order is a highly complex assignment, which requires considerable experience (which the students only start acquiring) and the ability to act publicly in the role of a commander (leader). The algorithm of issuing the battle order to subordinates in terrain was mastered by students very well theoretically. However, practical realization requires further training and repetition.

Table 2 - Average Assessment of Individual Combat Assignments

Таблица 2 - Средняя оценка отдельных боевых задач

Табела 2 - Просечна оцена појединачних борбених задатака

\begin{tabular}{|l|l|l|}
\hline Combat assignment & theory & practice \\
\hline Fire control & 9 & 8.9 \\
\hline Battle order & 8.3 & 6.6 \\
\hline Radio operation & 9.4 & 9.2 \\
\hline
\end{tabular}




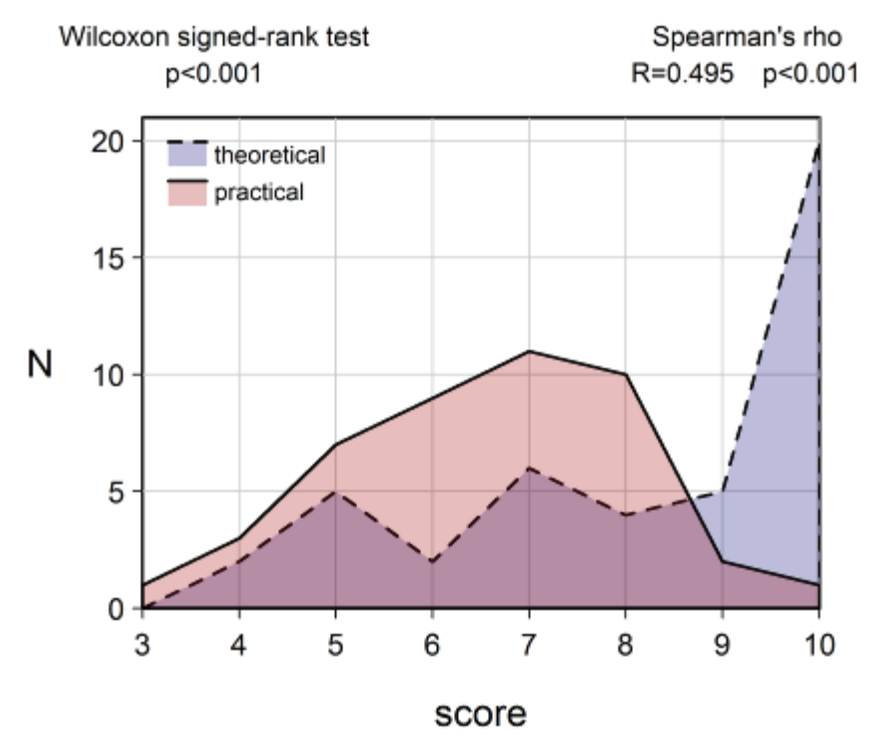

Figure 1 - Outcomes of assessing the "battle order" assignment Pис. 1 - Результаты оценивания задачи «боевой порядок» Слика 1 - Резултати оцењивања задатка "наређење за борбу"

On the other hand, the combat assignment called "fire control" did not show statistically significant difference between the outcomes of practical and theoretical parts (see Figure 2). The outcomes of all parts illustrated strong correlation $(r=0.621)$, which means that those soldiers who were successful in the theoretical part were successful also in the practical fulfilment of this task. Thus it may be assumed that the theoretical preparation for the fulfilment of this task is appropriate, because it increases soldiers' chances to succeed in practice. Squad commander fire control has very clearly determined rules and order of given tasks and, in the case of the battle order, it is much easier for the students to master this task in theory than to implement the acquired knowledge in practice. Fire control is not such a complex activity as the issuing of the battle order and it can be carried out without a direct contact with subordinates (each squad member has his/her role in the formation and the squad commander controls fire just by issuing clearly determined orders). Moreover, this assignment does not include so high requirements for students' expression capabilities as in the case of the battle order. 


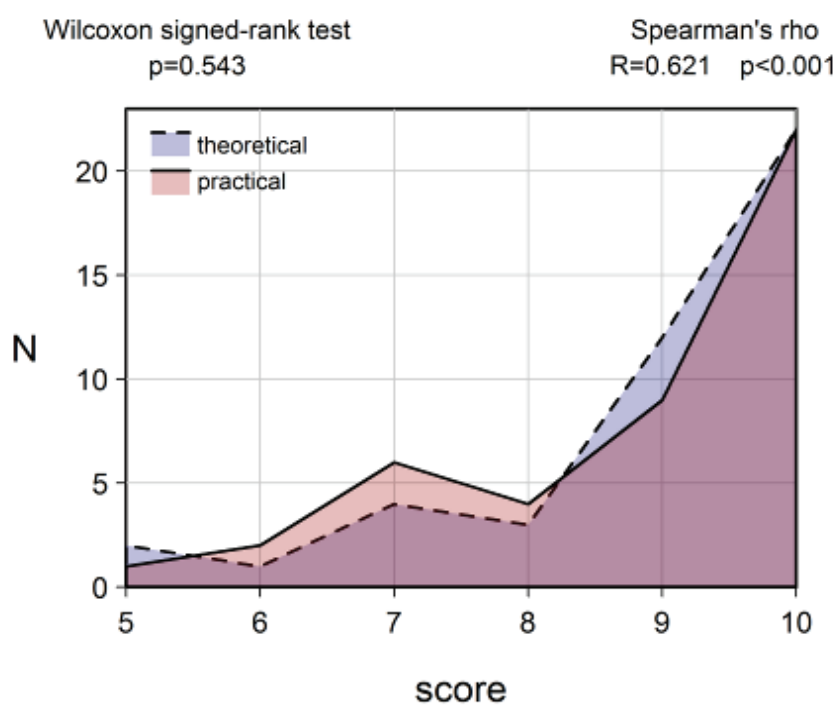

Figure 2 - Outcomes of assessing the "fire control" assignment Pис. 2 - Результаты оценивания задачи «управление огнем» Слика 2 - Резултати оцењивања задатка „управљање ватром"

The outcomes in the "radio operation" assignment are similar to those in the "fire control" assignment. No statistically significant difference was monitored between the outcomes of practical and theoretical parts. In contradistinction to the "fire control" assignment, there was only a weak correlation between the outcomes of theoretical and practical parts in the case of the "radio operation" assignment. Despite this fact, this correlation is statistically significant $(p=0.031)$ on the 0.05 significance level. The above mentioned correlation illustrates the fact that it was not difficult for the assessed soldiers to master the "radio operation" assignment. Practical fulfilment of such assignment is not pre-conditioned just by theoretical preparation, but other factors are involved as well. The theoretical mastering of radio-communication is a significant prerequisite for successful practice, in the same way as in the case of the "fire control" assignment. Moreover, the students carry out this activity usually not in the presence of the whole squad. Thus, radio-communication is not demanding as far as the performance in front of subordinates is concerned. Radio-communication has clearly set rules and routine terminology, so the theoretical mastering makes it easier to communicate through radio station. It is easy to handle a radio station, because it does not require any special technical knowledge. 


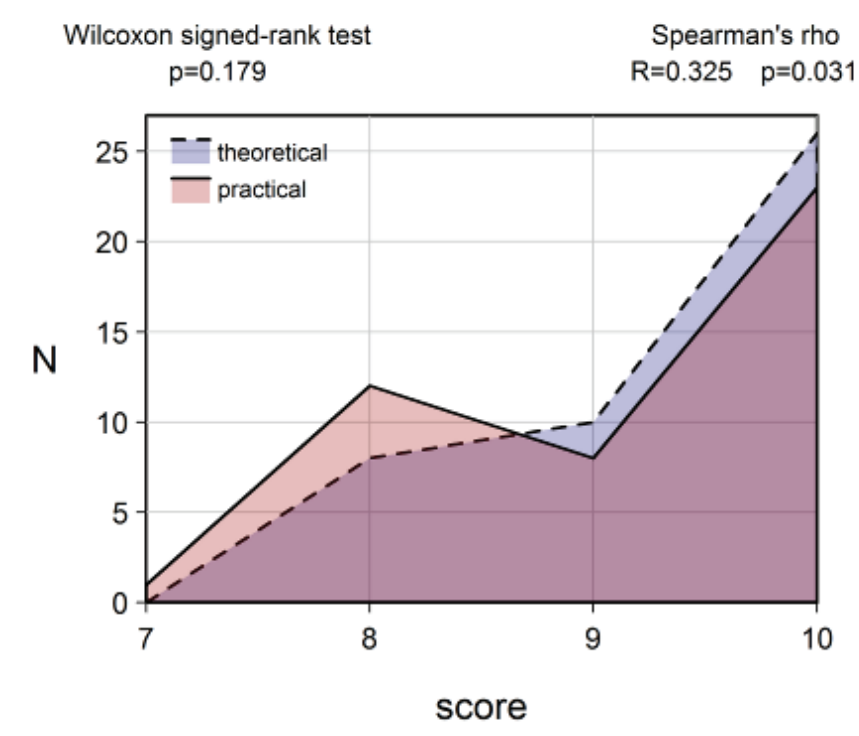

Figure 3-Outcomes of assessing the "radio operation" assignment Puс. 3 - Результаты оценивания задачи "организация радиосвязи» Слика 3 - Резултати оцењивања задатка "комуникација путем радија"

\section{Conclusion}

It may be stated on the basis of the acquired outcomes that the assessment of theoretical solutions of selected combat assignments fulfilled by future squad commanders may be used for the prediction of how successful the management of such assignments may be in practice. Significant correlations between the outcomes of theoretical and practical solutions were recorded mainly in the case of the "fire control" assignment. Certain discrepancy between the outcomes in both parts was monitored in the case of the "battle order" assignment, as the students achieved systematically worse outcomes during the practical fulfilment. Such an outcome is probably pre-conditioned by the complexity of this assignment, which is not only about learning individual steps, but also about the students' abilities to perform the roles of commanders. Fulfilment of such assignment requires, besides theoretical preparation, considerable personal experience, which the future commanders gain only through practice. Nevertheless, a medium-strong correlation between the assessment outcomes of theoretical and practical fulfilment of this assignment has been recorded even in that case.

\section{5}




\section{References}

Dayan, K., Kasten, R., \& Fox, S., 2002. Entry-level police candidate assessment center: An efficient tool for a hammer to kill a fly? . Personnel Psychology, 55(4), pp.827-849. Available at: http://dx.doi.org/10.1111/j.17446570.2002.tb00131.x.

Hroník, F., 2002. Poznejte své zaměstnance: Vše o Assessment Centre.Brno: ERA group. Kariéra. 1. vyd, ISBN 80-865-1720-9 (in Czech).

Hroník, F., 2007. Jak se nespálit podruhé: Strategie a praxe výběrového rízení.Brně: MotivPress. Vyd. 1. MBA study, ISBN 978-80-254-0698-4 (in Czech).

Love, K.G., \& DeAarmond, S., 2007. The validity of assessment center ratings and $16 \mathrm{PF}$ personality trait scores in police sergeant promotions: A case of incremental validity. Public Personnel Management, 36(1), pp.21-31. ISSN 0091-0260.

\section{ПРОЦЕСС ПРИНЯТИЯ РЕШЕНИЙ ПРИ ВЫПОЛНЕНИИ} ВОЕННЫХ ЗАДАЧ

\footnotetext{
Радек Митачек, Томас Земан, Ян Дрозд, Лубош Ондроусек, Дэвид Ульрих, Йиржи Дворжак

Университет обороны в г. Брно, Факультет военного управления, г. Брно, Республика Чехия
}

ОБЛАСТЬ: военные науки

ВИД СТАТЬИ: оригинальная научная статья

ЯЗЫК СТАТЬИ: английский

\section{Резюме:}

Предметом настоящей статьи является процесс принятия решений в кризисном управлении, с особым акцентом на Вооруженные силы Чешской Республики (курсанты Университета обороны в е. Брно). Исследование основано на наблюдениях за поведением 44 курсантов в различных тактических ситуациях, происходящих во время сложных трехнедельных полевых учений. Курсанты должны были выполнить следующие боевые задачи: управление огнем, боевой порядок и организация радиосвязи. До начала учений курсанты заполняли анкету-опросник, содержащий вышеупомянутые задачи. На основании полученных результатов можно утверждать, что оценивание теоретических решений отдельных боевых задач, которое будущие командиры подразделений привели в опросниках, может быть использовано при прогнозировании успешности управления анализируемыми боевыми задачами на практике.

Ключевые слова: Вооруженные силы Чешской Республики, солдат, пехотные подразделения, принятие решения, кризисная коммуникация. 
ПРОЦЕС ОДЛУЧИВАњА ТОКОМ ИЗВРШАВАЊА ЗАДАТАКА У ВОЈСЦИ

Радек Митачек, Томаш Земан, Јан Дрозд, Лубош Ондроушек,

Давид Уллрих, Јиржи Дворжак

Универзитет одбране у Брну, Факултет војног руковођења,

Брно, Чешка Република

ОБЛАСТ: војне науке

ВРСТА ЧЛАНКА: оригинални научни чланак

ЈЕЗИК ЧЛАНКА: енглески

Сажетак:

Чланак се бави процесом одлучивања у кризном менаименту с нагласком на војску Републике Чешке (кадети на Универзитету одбране у Брну). Током истраживања, посматрана су 44 кадета у различитим тактичким ситуацијама током сложене тронедељне вежбе на терену. Од њих се тражило да изврше следеће борбене задатке: управљање ватром, наређење за борбу и комуникација путем радија. Пре тренинга, кадети су попунили упитник са питањима која су одговарала горе поменутим задацима у пракси. На основу добијених резултата, може се тврдити да оцена теоријског решавања изабраних борбених задатака међу будућим командирима јединица може да се користи за предвиђање успешности руковођења таквим задацима у пракси.

Кључне речи: Војска Републике Чешке, војник, јединица пешадије, процес одлучивања, кризно комуницирање.

Paper received on / Дата получения работы / Датум пријема чланка: 14.09.2017. Manuscript corrections submitted on / Дата получения исправленной версии работы / Датум достављања исправки рукописа: 27.09.2017.

Paper accepted for publishing on / Дата окончательного согласования работы / Датум коначног прихватања чланка за објављивање: 29.09.2017.

(c) 2017 The Authors. Published by Vojnotehnički glasnik / Military Technical Courier (www.vtg.mod.gov.rs, втг.мо.упр.срб). This article is an open access article distributed under the terms and conditions of the Creative Commons Attribution license (http://creativecommons.org/licenses/by/3.0/rs/).

() 2017 Авторы. Опубликовано в «Военно-технический вестник / Vojnotehnički glasnik / Military Technical Courier» (www.vtg.mod.gov.rs, втг.мо.упр.срб). Данная статья в открытом доступе и распространяется в соответствии с лицензией «Creative Commons» (http://creativecommons.org/licenses/by/3.0/rs/).

() 2017 Аутори. Објавио Војнотехнички гласник / Vojnotehnički glasnik / Military Technical Courier (www.vtg.mod.gov.rs, втг.мо.упр.срб). Ово је чланак отвореног приступа и дистрибуира се у складу са Creative Commons licencom (http://creativecommons.org/licenses/by/3.0/rs/).

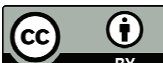

